|Araştırma Makalesi / Research Article |

\title{
Okul Öncesi Öğretmenlerinin Sınıf Yönetimi Becerileri İle Mesleki Profesyonellikleri Arasındaki ilişkinin İncelenmesi ${ }^{1}$
}

\section{Analyzing the Relationship Between Preschool Teachers' Classroom Management Skills and Occupational Professionalism}

\section{Rengin Zembat' ${ }^{2}$ Gülşen Illçi Küsmüşs}

Anahtar Kelimeler

sınıf yönetimi

mesleki profesyonellik

okul öncesi öğretmenleri

\section{Keywords}

classroom management

occupational

professionalism

preschool teachers

Başvuru Tarihi/Received

22.02.2019

Kabul Tarihi /Accepted

10.10.2019
Öz

Bu araştırmada, okul öncesi öğretmenlerinin sınıf yönetimi becerileri ile mesleki profesyonellikleri arasındaki ilişkinin incelenmesi amaçlanmıştır. Tarama modelinde yürütülen araştırmanın çalışma grubunu, 2017-2018 eğitim-öğretim yılında Millî Eğitim Bakanlığı'na bağlı devlet kurumlarında görev yapmakta olan 438 okul öncesi öğretmeni oluşturmaktadır. Araştırmada veri toplama aracı olarak; "Kişisel Bilgi Formu”, "Okul Öncesi Öğretmenleri için Sınıf Yönetimi Becerileri Ölçeği” ve "Öğretmenlerin Mesleki Profesyonelliği Ölçeği" kullanılmıştır. Elde edilen verilerin analizinde Pearson Çarpım Momentler Korelasyon Katsayısı, tanımlayıc istatistikler (yüzde, frekans, ortalama ve standart sapma) ve fark testleri (Tek Yönlü Varyans Analizi (ANOVA), Kruskal Wallis-H Testi ve Post Hoc Analizi) kullanılmıştır. Yapılan analizler sonucunda, okul öncesi öğretmenlerinin sınıf yönetimi becerileri ile mesleki profesyonellikleri arasında orta düzeyde, pozitif yönlü ve anlamlı bir ilişki olduğu bulunmuştur. Ayrıca okul öncesi öğretmenlerinin sınıf yönetimi becerilerinin yaş, öğrenim durumu, mesleki kıdem, sınıfta bulunan çocuk sayısı ve eğitim verilen yaş grubu değişkenlerine göre anlamlı düzeyde farklılaştığı; öğretmenlerin mesleki profesyonelliklerinin ise yaş, eğitim durumu, mesleki kıdem değişkenlerine göre anlamlı düzeyde farklılaştığı belirlenmiştir.

\section{Abstract}

The aim of this research is to analyze the relationship between preschool teachers' classroom management skills and occupational professionalism. The sample of the study conducted in the screening model is 438 pre-school teachers who work in state institutions affiliated to the Ministry of National Education in 2017-2018 academic year. As data collection tools, "Personal Information Form" "Classroom Management Skills Inventory for Preschool Teachers and also "Occupational Professionalism of Teachers Scale" were used in the study. In the analysis of data obtained, Pearson Product-Moment Correlation Coefficient analysis technique, descriptive statistics (percentage, frequency, mean and standard deviation) and difference tests (one-way analysis of variance-ANOVA, Kruskal Wallis-H Test and Post Hoc Analysis) were used. In line with analysis, a significant positive moderate correlation was found between preschool teachers' classroom management and occupational professionalism. It was also determined that preschool teachers' classroom management significantly differ according to their age, educational level, professional seniority, number of students and age group they teach; teachers' occupational professionalism also significantly differ according to their age, educational level and professional seniority.

\footnotetext{
${ }^{1}$ Bu makale sorumlu yazarın yüksek lisans tezinden türetilmiştir.

${ }^{2}$ Maltepe Üniversitesi, Eğitim Fakültesi, Temel Eğitim Bölümü, İstanbul, TÜRKiYE; http://orcid.org/0000-0002-2377-8910

${ }^{3}$ Sorumlu Yazar, Marmara Üniversitesi, Atatürk Eğitim Fakültesi, Temel Eğitim Bölümü, İstanbul, TÜRKiYE; https://orcid.org/0000-0003-2885-1176
}

Alıntı/Citation: Zembat, R., \& İlçi-Küsmüş, G. (2020). Okul öncesi öğretmenlerinin sınıf yönetimi becerileri ile mesleki profesyonellikleri arasındaki ilişkinin incelenmesi. Kastamonu Education Journal, 28(4), 1725-1739. doi: 10.24106/kefdergi.3621 


\section{Extended Abstract}

\section{Introduction}

Continuing education without intervals, teacher and children spending time together throughout the educational period, children adapting to the rules and going through the self-regulation process in preschool education classrooms increase the importance of the preschool teacher and classroom management (Dinçer, Deniz, Akgün and Ulubey, 2018). With its broadest meaning, classroom management refers to; organizing educational activities for academic attendance and achievement, many behavior implementations and behavior management in the education given (Sugai and Horner, 2002).

Fulfilling goals in the field of education is closely related to the qualifications and competences of teachers who direct this process (MNE, 2017a). Professionalism is stated as one of the qualifications necessary for the teaching profession (Demirel, 2006). Professionalism refers to; carrying out an occupation in the best way, performing it skillfully and sustain the job with one's experiences. In addition, strategies or duties arranged to carry out a profession the best way also point out the beliefs and actions of the people who practice that occupation (Hargreaves and Goodson, 1996). The focus of carrying out the teaching profession in a professional manner is the importance of students experiencing a high quality and competent teaching (Phelps, 2003).

When occupational professionalism and classroom management terms are considered, we can state that both terms contain teacher competence and they both affect each other. Studies show that the classroom management skill is within teacher competence. When special field competences of preschool teaching are considered; classroom management is included in "Development Areas" and "Communication" fields of competence (MNE, 2017b). For this reason, having an effective classroom management skill is important for these areas of competence. Academic experiences of students educated in classrooms where there are teachers who perform their occupation professionally and have a good classroom management skill are thought to be positively affected. Thus, it is important to examine the relationship between these two concepts. For all these reasons, the purpose of this study was set as examining the relationship between classroom management skills and occupational professionalism skills of preschool teachers according to various variables and based on this main purpose, answers for the following questions were sought:

1. Do classroom management skills and occupational professionalism of preschool teachers differ meaningfully according to demographic properties such as age, education level, professional seniority, the number of children in the classroom and age group they teach?

2. Is there any meaningful relation between classroom management skills and occupational professionalism of preschool teachers?

\section{Method}

This research designed with with relational scanning model as one of quantitative research methods.

Universe and Sample: The universe of the study consists of preschool teachers working in public schools under the Ministry of National Education in the province of İstanbul during the 2017-2018 academic years. According to İstanbul Provincial Directorate of National Education Department of Strategy Development 2016-2017 statistical data, the number of preschool teachers working in public and private schools in İstanbul is "10.265" (Yücel and Kakırman, 2017). When the study sample was calculated; the sample calculation table developed by Yazıcıŏlu and Erdoğan was used to help the researchers and the number of sample that was needed to be selected was about 370 with 0.05 sample error and 0.5 possibility. 550 teachers were accessed for the study, scales which did not fit the implementation criteria were excluded from the study and the remaining 438 teachers constituted the study sample. It is evident that the selected number of samples is sufficient based on these values. The random sampling method was conducted when selecting the districts where the teachers in the sample group were working. After this stage, the Kağıthane, Şişli and Fatih districts in the European Side; the Kadıköy, Üsküdar and Kartal districts in the Anatolian Side were included in the study group. All the schools in the districts were contacted; teachers working in these schools who wished to volunteer participated in the study. The study group of the research consists of 438 preschool teachers who work in kindergartens depend on ministry of national education in Istanbul in 2017-2018 years. Simple random sampling method is used while counties where teachers work in the study group are chosen. In this direction, Kağıthane, Şişli and Fatih are chosen from European side of the city and also Kadıköy, Üsküdar and Kartal are chosen from Asian side.

Data Collection Tool: As data collection tools, "Personal Information Form" developed by researcher, "Classroom Management Skills Inventory for Preschool Teachers" by Dinçer and Akgün (2015) and also "Occupational Professionalism of Teachers Scale" developed by Yılmaz and Altınkurt (2014) were used in the study.

Data Analysis: In the analysis of data obtained, Pearson Product-Moment Correlation Coefficient analysis technique was used to determine the relationship between preschool teachers' classroom management skills and occupational professionalism. In the analysis of teachers' classroom management and occupational professionalism according to some variables (age, educational level, professional seniority, number of students and age group they teach), descriptive statistics (percentage, frequency, mean and standard deviation) and difference tests (one-way analysis of variance-ANOVA, Kruskal Wallis-H Test and Post Hoc Analysis) were used.

Findings: This research was conducted in order to analyze the relationship between preschool teachers' classroom management skills and occupational professionalism and also to examine teachers' classroom management skills and occupational professionalism in terms of some variables (age, educational level, professional seniority, number of students and age group they teach). According to the results of the research:

1. In the research, classroom management skills and professional professionalism of preschool teachers were examined according to their own perceptions. According to the results of the research, the mean scores of classroom management skills and professional professionalism scores of preschool teachers were found to be relatively close to the maximum score that can be obtained from the scales. Based on this result, it can be said that teachers consider themselves sufficient in terms of classroom management and professional professionalism. 
2. A significant positive moderate correlation is found between preschool teachers' classroom management and occupational professionalism. That is classroom management skills increase together with occupational professionalism of preschool teachers.

3. Classroom management skills and occupational professionalism of preschool teachers differ according to age. Classroom management skills and occupational professionalism of preschool teachers increase together with age.

4. Classroom management skills and occupational professionalism of preschool teachers differ according to educational level. Classroom management skills and occupational professionalism of preschool teachers increase together with education level.

5. Classroom management skills and occupational professionalism of preschool teachers differ according to professional seniority. Classroom management skills and occupational professionalism of preschool teachers increase together with professional seniority.

6. Classroom management skills of preschool teachers differ according to number of students, but occupational professionalism of preschool teachers does not differ. Classroom management skills of preschool teachers increase together with the number of children.

7. Classroom management skills of preschool teachers differ according to age group they teach but occupational professionalism of preschool teachers not differ. Classroom management skills of preschool teachers increase together with the age of the group which education is served.

In line with the results, we conclude that classroom management skills and occupational professionalism of preschool teachers are found at high level. A significant positive moderate correlation is found between preschool teachers' cclassroom management and occupational professionalism. That is classroom management skills increase together with occupational professionalism of preschool teachers. Besides, it is also determined that preschool teachers' classroom management significantly differ according to their age, educational level, professional seniority, number of students and age group they teach; teachers' occupational professionalism also significantly differ according to their age, educational level and professional seniority. Dealing with occupational professionalism by considering its relationship with classroom management skills has a great importance. It is suggested that steps should be taken by training teacher candidates during graduate education so as to improve preschool teachers' classroom management skills and to provide them with seminar and workshop activities so as to support their classroom management skills during their education. 
İnsan hayatının şekillenmesinde aileden sonra ilk konumda öğretmen bulunmaktadır. Bu noktada erken çocukluk döneminde öğretmenin sevgi dolu, sabırlı ve sevecen olması gibi bireysel özelliklerinin yanı sıra kendisinden beklenen; iyi bir sınıf yönetimi becerisine sahip olması, organizasyon ve değerlendirme becerisine sahip olması, öğretimi iyi planlayabilmesi, yeniliklere açık olması, teknolojiyi eğitim amaçlı kullanabilmesi ve çok kültürlü ortamlarda çalışabilen bir kişi olmasıdır.

Okul öncesi eğitimin verildiği sınıflarda, eğitimin ara vermeden sürdürülmesi, yine öğretmen ve çocukların eğitim süresi boyunca kesintisiz birlikte zaman geçirmesi, çocukların kurallara adapte olma ve öz düzenleme sürecinde olmaları, okul öncesi öğretmeninin ve sınıf yönetiminin önemini arttırmaktadır (Dinçer, Deniz, Akgün ve Ulubey, 2018). En geniş anlamıyla sınıf yönetimi; verilen eğitimde, akademik katılım ve başarı için eğitsel faaliyetlerin düzenlenmesi, çok sayıda davranış uygulamaları ve davranış yönetimini içerir (Sugai ve Horner, 2002).

Öğretmenlerin çocukların eğitimi için eğitsel faaliyetleri ve davranışları düzenlediği sınıf yönetimi; yürütme ve öğretmen-çocuk ilişkisi aşamalarından oluşmaktadır. Yürütme aşaması eğitsel faaliyetlerin düzenlenmesi için fiziksel ortamın hazırlanması, zamanın etkili kullanımı, davranış düzenlemeleri, sınıf kurallarının oluşturulması, eğitime engel olan problemlerin çözümü gibi görevleri içinde barındırırken; öğretmen-çocuk etkileşimi, etkili iletişim ortamı oluşturma, çocukları motive etme, çocukları sorumluluk almaları için teşvik etme çocukların özsaygılarının gelişmesine yardımcı olma, davranışlara yönelik dönüt verme ve değerlendirme yapma gibi görevleri içerir (Kayabaşı,2009; Alkan, 2007; Denkdemir, 2007; Yılmaz, 2006; Erden, 2005; Başar, 1999). Öğretmenlerin bu görevleri yerine getirebilmeleri için belli yeterliklere sahip olması gerekir.

Eğitim alanında istenilen hedeflere ulaşabilmek, bu sürece yön veren öğretmenlerin nitelik ve yeterlikleriyle yakından ilişkilidir (MEB, 2017a). Öğretmen yeterliği ya da niteliği uzun yıllardır üzerinde durulan ve çalışılan bir konudur. Öğretmen yeterliği ile ilgili ülkemizde Milli Eğitim Bakanlığı (MEB) ve Yüksek Öğretim Kurumu (YÖK) tarafından yürütülen çalışmalara rastlanmıştır. Milli Eğitim Temel Kanununda öğretmen yeterliliklerinin belirlenmesi bu çalışmalardan biridir. Bir diğeri ise YÖK tarafından belli aralıklarla güncellenen öğretmen yetiştirme programlarıdır. Bu çalışmalarda YÖK nitelikli ve çağa uygun donanımda öğretmen yetiştirmeyi amaçlamıştır. MEB tarafından yürütülen öğretmen yeterliği çalışmalarında 6 ana yeterlik, 31 alt yeterlik ve 233 performans göstergesi belirlenmiştir (Özdemir, 2017). Bu sayede, çocuklarla uzun süreli etkileşimde bulunan öğretmenlerin nitelikli ve yeterli olmaları hedeflenmiştir.

Öğretmenlik mesleğinde bulunması gereken niteliklerin içinde profesyonellik de belirtilmiştir (Demirel,2006). Profesyonellik; bir mesleği en iyi şekilde yapmak, ustaca uygulamak, sahip olduğu deneyimle o işi sürdürebilmektir. Ayrıca bir mesleğin en iyi şeklide yürütülmesi için hazırlanan strateji ya da görevler o mesleği icra eden kişilerin inanç ve eylemlerini de ortaya koymaktadır (Hargreave ve Goodson, 1996). Toplumda gerçekleşmesi gereken görev, ne kadar karmaşık ve zorsa profesyonelleşme o kadar önem kazanır. Bu nedenle toplumdaki işlerde görevli tüm bireylerden işlerini profesyonellikle yapmayı içselleştirmiş olmaları beklenmektedir (Gökçora, 2005). Mesleki profesyonellik ise profesyonelliğin bireysellikten çıkıp örgütselliğe ulaşma boyutudur. Yani sadece çalışanların bireysel profesyonel olmaları değil, örgütçe tüm çalışanların profesyonel olma durumudur (Adıgüzel, Tanrıverdi ve Sönmez-Özkan, 2011). Profesyonel meslek denildiğinde net bir tanım getirilemese de genelde profesyonel meslek olarak akla ilk gelen alan Tıp ve Hukuk olmuştur (Strike, 1990). Fakat aslında her meslek kendine özgü özel yetenek gerektirir. Bu nedenle profesyonellik, öğretmenlik mesleğinde de olması gereken bir niteliktir ve öğretmenlikte başarılı özellikleri betimler (Kagan, 1992).

Öğretmenliğin profesyonel olarak yürütülmesinin odağında öğrencilerin kaliteli ve nitelikli öğrenmelerine olan önem vardır (Phelps, 2003). Profesyonellik için nitelik mutlaka olması gereken bir olgudur. Niteliği yüksek, her koşulda ve işte niteliği arayan, bunu hayat felsefesi edinmiş ve aynı niteliği öğrencilerine aşılayan ve onların yaptığı her çalışmada da nitelik arayan öğretmenler sayesinde öğretmenlik, profesyonel bir meslek olarak kabul edilecektir (Altan, 2017). Çünkü profesyonel öğretmenler; bir grup çocuğa önceden hazırlanmış materyaller yoluyla beceri, davranış ve tutum aktaran biri değil, öğretim sürecinde aktif birer rol oynayıcı olmalıdır (Feinberg, 1987; Akt. Addie, 2005). Bu nedenle nitelik sahibi öğretmenlerden işlerini profesyonelce yapmaları beklenmektedir.

İlgili literatür incelendiğinde Türkiye'de öğretmenlerin mesleki profesyonellikleri ile ilgili çeşitli araştırmalar bulunmakla birlikte, (Yirci, 2017; Çelik-Yılmaz, 2017; Çelik ve Yılmaz, 2015; ilgan, Arslanargün ve Shaukat, 2015; Altınkurt ve Yılmaz, 2014; Bayhan, 2011; Demirkasımoğlu, 2010; Güven, 2010) okul öncesi öğretmenlerinin mesleki profesyonelliklerinin incelendiği araştırmalara rastlanmamıştır. Mesleki yeterlik hakkında yapılan çalışmalara bakıldığında; Kanbay-Ak, Yıldırım ve Kadıoğlu-Ateş (2016), tarafından okul öncesi öğretmenlerinin mesleki yeterlik algıları incelenmiş ve araştırma sonucunda, okul öncesi öğretmenlerinin çoğunluğunun mesleki yeterlilik konusunda kendilerini yeterli gördüğü ve gelişime açık oldukları belirtilmiştir. Bağ (2015), araştırmasında okul öncesi öğretmenlerinin öğretmen yeterlikleri ve hizmet içi eğitim ihtiyaçlarını yönetici ve öğretmen gözüyle değerlendirmiştir. Yapılan bir diğer çalışmada; anasınıfı ve sınıf öğretmenlerinin mesleki yeterliklerine ilişkin algı düzeyi incelenmiş ve anasınıfı öğretmenlerinin mesleki yeterlik algılarının yüksek düzeyde olduğu sonucuna ulaşılmıştır (Çabuk, 2014). Söz konusu çalışmada kullanılan ölçeğin "Yönetim Yeterliği Algı Düzeyi” boyutu sınıf yönetimi ve idari konularla ilgili becerileri kapsamaktadır. Dolayısıyla sınıf yönetimi becerisinin öğretmenlerin mesleki yeterliklerine olumlu yönde katkı sağladığı söylenebilir. Türkeç-Aktaş (2012), araştırmasında okul öncesi öğretmenlerinin yeterlilik düzeylerini, Milli Eğitim Bakanlığı'nın “Okul Öncesi Öğretmeni Özel Alan Yeterlikleri" ifadelerinden yola çıkarak hazırlamış olduğu ölçekle incelemiş ve araştırma sonucunda, okul öncesi öğretmenlerin ölçme aracında yer alan maddelerin tümüne ilişkin katılımları genellikle "tamamen katılıyorum" düzeyinde olmuştur. Okul öncesi 
öğretmenliği özel alan yeterliklerine bakıldığında; sınıf yönetimi, yeterlik alanlarından "Gelişim Alanları" ve "iletişim" alanında karşımıza çıkmaktadır (MEB, 2017b). Bu nedenle etkili bir sınıf yönetimi becerisine sahip olmak, bu yeterlik alanları açısından önem kazanmaktadır.

Okul öncesi öğretmenlerinin sınıf yönetimi becerilerinin incelendiği araştırmalara bakıldığında; çok sayıda araştırmanın bulunduğu görülmektedir. Bu çalışmalarda; ölçek geliştirme çalışmaları yapılmış (Dinçer, Deniz, Akgün ve Ulubey, 2018; Dinçer ve Akgün, 2015), okul öncesi öğretmenlerinin sınıf yönetimi becerileri ile problem çözme becerileri (Zembat, Tunçeli ve Akşin Yavuz, 2017), sınıf yönetimi becerileri ile tükenmişlik düzeyleri (Adıgüzel ve İpek 2016), okulöncesi öğretmenlerinin öz-yeterlik algılarının ve sınıf yönetimi stratejilerinin çocuk- öğretmen ilişkileri üzerindeki etkileri (Demir, 2015), okul öncesi öğretmen adaylarının ve okul öncesi öğretmenlerinin sınıf yönetimine ilişkin tutum ve inançları (Keleş, 2013) incelenmiş, okul öncesi eğitimde etkili sınıf yönetimi becerilerini geliştirmeye yönelik hizmet içi eğitim programı (Yeşilay Daşıran, 2013) tasarlanmış, anaokullarında örgüt iklimi ile öğretmenlerin sınıf yönetimi becerileri (Nur, 2012), okul öncesi öğretmenlerin sınıf içi etkinliklerde kullandıkları sınıf yönetimi stratejileri (Akgün, Yarar ve Dinçer, 2011), öğretmenlerin sınıf yönetimi yaklaşımları ve deneyimleri (Akar, Tor, Tantekin Erden ve Şahin 2010) incelenmiştir.

Sınıf yönetimi becerisi ile mesleki profesyonelliğin incelendiği araştırmalardan birinde öğretmenlerin sınıf yönetimi yeterlikleri ile mesleki profesyonellikleri arasındaki ilişki genel olarak incelenmiş; çalışmada tüm öğretmenler ele alınmıştır (Karaman, 2016). Diğer çalışmada ise okul öncesi öğretmenlerinin çocuk sevgileri ve mesleki benlik saygıları profesyonellik değişkenleri açısından incelenmiştir (Sarı, 2016). Meslek profesyonelliği ve sınıf yönetimi kavramlarına bakıldığında ikisinin de öğretmen yeterliğini içinde barındırdığını ve bu kavramların birbirini etkilediğini söyleyebiliriz. Yukarıda da belirtildiği üzere sınıf yönetimi becerisi mesleki yeterliğe dolayısıyla mesleki profesyonelliğe olumlu yönde katkı sağlamaktadır Mesleğini profesyonelce yürüten ve iyi bir sınıf yönetimi becerisine sahip öğretmenlerin sınıflarında yetişen çocukların akademik yaşantılarının da olumlu yönde etkileneceği düşünülmektedir. Dolayısıyla bu iki kavramın birbiriyle ilişkisinin incelenmesi bu açıdan önem arz etmektedir. Kritik yılları içine alan okul öncesi eğitimin niteliğinin arttırılmasında da öğretmen profesyonelliğinin etkili olacağı düşünülmektedir. Bu alanda yapılan çalışmaların sınırlı olması nedeniyle okul öncesi öğretmenlerinin mesleki profesyonelliklerinin incelendiği araştırmalara yer verilmesinin önemi karşımıza çıkmaktadır. Okul öncesi dönem çocukların fiziksel, bilişsel, sosyal ve duygusal açıdan çok yönlü gelişimleri için kritik bir dönemi içermektedir ve bu dönemde çocukların aileden sonra ilk karşılaştıkları öğretmenleri olmaktadır. Bu nedenle de eğitimcinin rolü son derece önemlidir. Öğretmenin iyi bir sınıf yönetimine ve mesleki profesyonelliğe sahip olması, verdikleri eğitimin kalitesini etkileyebilir. Sınıf yönetimi becerisi ve mesleki profesyonelliği iyi olmayan öğretmen, çocuklara kaliteli bir eğitim sunamayabilir.

Tüm bu nedenlerden dolayı; bu araştırmanın amacını, okul öncesi öğretmenlerinin sınıf yönetimi becerileri ile mesleki profesyonellikleri arasındaki ilişkinin ve öğretmenlerin sınıf yönetimi becerileri ve mesleki profesyonelliklerinin çeşitli değişkenlere göre incelenmesi oluşturmuş ve bu temel amaç doğrultusunda, aşağıdaki sorulara cevap aranmıştır:

1. Okul öncesi öğretmenlerinin sınıf yönetimi becerileri ile mesleki profesyonellikleri arasında anlamlı ilişki var mıdır?

2. Okul öncesi öğretmenlerinin sınıf yönetimi becerileri ve mesleki profesyonellikleri demografik özelliklerine (yaş, öğrenim durumu, mesleki kıdem, sınıfta bulunan çocuk sayısı ve eğitim verilen yaş grubu) göre anlamlı düzeyde farklılaşmakta mıdır?

\section{YÖNTEM}

Araştırmanın bu bölümünde sırası ile araştırmanın modeli, evren ve örneklem, veri toplama araçları, veri toplama süreci ve verilerin analizinde kullanılan istatistiksel tekniklere ilişkin bilgilere yer verilmiştir.

\section{Araştırma Modeli}

$\mathrm{Bu}$ araştırmada, okul öncesi öğretmenlerinin sınıf yönetimi becerileri ile mesleki profesyonellikleri arasındaki ilişki incelendiğinden, betimsel tarama modelinde ilişkisel tarama yöntemi kullanılmıştır.

\section{Evren ve Örneklem}

Araştırmanın evrenini 2017-2018 yılında, İstanbul'da Milli Eğitim Bakanlığı'na bağlı devlet okullarında görev yapmakta olan okul öncesi öğretmenleri oluşturmaktadır. İstanbul il Milli Eğitim Müdürlüğü Strateji Geliştirme Bölümü 2016-2017 istatistik verilerine göre İstanbul'da devlet okulları ve özel okullarda görev yapmakta olan okul öncesi öğretmeni sayısı "10265" tir (Yücel ve Kakırman, 2017). Araştırmanın örneklemi hesaplanırken; araştırmacılara kolaylık sağlaması bakımından Yazıcıoğlu ve Erdoğan (2004:50)'a ait örneklem hesaplama tablosundan yararlanılmış ve seçilmesi gereken örneklem sayısının; 0.05 örnekleme hatası ve 0.5 olasılık ile yaklaşık 370 olduğu görülmüştür. Araştırmada 550 öğretmene ulaşılmış, uygulama ölçütlerine uymayan ölçekler çıkarıldıktan sonra geriye kalan 438 öğretmen, araştırmanın örneklemini oluşturmuştur. Seçilen örneklem sayısının bu değerlere göre yeterli sayıda olduğu görülmektedir. Örneklem grubundaki öğretmenlerin görev yaptıkları ilçeler seçilirken basit tesadüfi örnekleme yönteminden yararlanılmıştır. Bu işlemin sonucunda Avrupa Yakası'nda bulunan Kağıthane, Şişli ve Fatih ilçeleri; Anadolu Yakası'nda bulunan Kadıköy, Üsküdar ve Kartal ilçeleri örneklem grubuna dahil edilmiştir. İlçelerdeki tüm okullara ulaşılmış; okullarda görev yapan öğretmenlerin ise katılımı gönüllülük esasına göre sağlanmıştır. Araştırmanın örneklemini oluşturan öğretmenlere ilişkin demografik bilgiler tablo 1'de sunulmuştur. 
Tablo 1. Araştırmaya katılan öğretmenlerin demografik bilgilerine ilişkin frekans ve yüzde değerleri

\begin{tabular}{|c|c|c|c|}
\hline & & $f$ & $\%$ \\
\hline \multirow{6}{*}{ Görev Yapılan İlçe } & Fatih & 72 & 16,4 \\
\hline & Kadıköy & 85 & 19,4 \\
\hline & Kağıthane & 82 & 18,8 \\
\hline & Kartal & 68 & 15,6 \\
\hline & Şişli & 64 & 14,6 \\
\hline & Üsküdar & 67 & 15,2 \\
\hline \multirow{2}{*}{ Cinsiyet } & Kadın & 432 & 98,6 \\
\hline & Erkek & 6 & 1,4 \\
\hline \multirow{4}{*}{ Yaş } & $21-25$ & 116 & 26,5 \\
\hline & $26-30$ & 115 & 26,3 \\
\hline & $31-35$ & 100 & 22,8 \\
\hline & 36 ve üstü & 107 & 24,4 \\
\hline \multirow{3}{*}{ Öğrenim Durumu } & Ön lisans & 55 & 12,6 \\
\hline & Lisans & 356 & 81,2 \\
\hline & Yüksek lisans & 27 & 6,2 \\
\hline \multirow{4}{*}{ Mesleki Kıdem } & $0-5 \mathrm{yll}$ & 163 & 37,2 \\
\hline & $6-10$ yıl & 138 & 31,5 \\
\hline & $11-15$ yıl & 85 & 19,4 \\
\hline & 16 ve üstü yıl & 52 & 11,9 \\
\hline \multirow{3}{*}{ Sınıfta Bulunan Çocuk Sayısı } & 15 ve daha az & 102 & 23,3 \\
\hline & $16-20$ & 220 & 50,2 \\
\hline & $21-25$ & 116 & 26,5 \\
\hline \multirow{4}{*}{ Eğitim Verilen Yaş Grubu } & 48 ay & 129 & 29,5 \\
\hline & $49-60$ ay & 157 & 35,8 \\
\hline & $61-72$ ay & 152 & 34,7 \\
\hline & Toplam & 438 & 100 \\
\hline
\end{tabular}

Tablo 1'e göre araştırmaya katılan öğretmenlerin \%16,4 'ü Fatih, \%19,4'ü Kadıköy, \%18,8'i Kağıthane, \%15,6'sı Kartal, \%14,6'sı Şişli ve \%15,2'si Üsküdar ilçelerinde görev yapmaktadırlar. Araştırmaya katılan öğretmenlerin \%26,5'i 21-25 yaş aralığına, \%26,3'ü 26-30 yaş aralığına, \%22,8'i 31-35 yaş aralığına ve \%24,4'ü ise 36 ve üstü yaş aralığına sahiptir. Araştırmada; öğretmenlerin $\% 12,6^{\prime}$ sının ön lisans, \%81,2'sinin lisans ve \%6,2'sinin yüksek lisans düzeyinde öğrenim aldığı görülmektedir. Araştırmaya katılan öğretmenlerin \%37,2'si 0-5 yıl, \%31,5'i 6-10 yıl, \%19,4'ü 11-15 yıl ve \%11,9'u 16 ve üstü yıl mesleki kıdeme sahiptir. Öğretmenlerin \%23,3'ünün sınıfında 15 ve daha az sayıda çocuk, \%50,2'sinin sınıfında 16-20 sayıda çocuk ve \%26,5'inin sınıfında 21-25 sayıda çocuk bulunmaktadır. Öğretmenlerin \%29,5'i 48 aylık, \%35,8'i 49-60 aylık ve \%34,7'si 61-72 aylık çocuklara eğitim vermektedir. Araştırma Milli Eğitim Bakanlığı’na bağlı devlet okullarında yürütüldüğünden, çocukların ay olarak yaşları araştırmanın yürütüldüğü okullarda 48.aydan itibaren başlamaktadır. 48 aylık çocuk sayısı fazla olduğundan aralıklar oluşturulurken 48. aydan başlanmıştır.

\section{Veri Toplama Araçları}

Araştırmada öğretmenlerin demografik bilgilerini elde etmek için "Kişisel Bilgi Formu", sınıf yönetimi becerilerini belirlemek için Dinçer ve Akgün (2015) tarafından geliştirilen "Okul Öncesi Öğretmenleri için Sınıf Yönetimi Becerileri Ölçeği" ve mesleki profesyonelliklerini belirlemek amacıyla Yılmaz ve Altınkurt (2014) tarafından geliştirilen “Öğretmenlerin Mesleki Profesyonelliği Ölçeği" olmak üzere 3 adet veri toplama aracı kullanılmıştır.

\section{Okul Öncesi Öğretmenleri için Sınıf Yönetimi Becerileri Ölçeği}

“Okul Öncesi Öğretmenleri için Sınıf Yönetimi Becerileri Ölçeği”, Dinçer ve Akgün (2015) tarafından okul öncesi öğretmenlerinin sınıf yönetimi becerilerinin kendi algılarına göre belirlenmesini ölçmek amacıyla geliştirilmiştir. 520 okul öncesi öğretmeniyle yapılan geçerlik ve güvenirlik çalışması sonuçlarına göre; ölçeğin faktör yükleri 0.301-0.677 arasında değişmektedir. Ölçekte iki alt boyut bulunmaktadır. Mesleki beceriler alt boyutunda 31; öğretmen çocuk etkileşimi alt boyutunda ise toplam 9 madde yer almaktadır. Ölçeğin tamamı 40 maddeden oluşmaktadır. Ölçeğin Cronbach alfa iç tutarlık katsayısı mesleki beceriler alt boyutu için 0.88; öğretmen çocuk etkileşimi alt boyutu için 0.70; ölçeğin tamamı için 0.83 olarak hesaplanmıştır. Beşli likert yapıdaki ölçek "hiç tanımlamıyor" ve "tamamen tanımlıyor" aralığında puanlanmaktadır. Ölçekten alınabilecek puanlar 200-40 arasında değişmektedir (Dinçer ve Akgün, 2015).

\section{Öğretmenlerin Mesleki Profesyonelliği Ölçeği}

Öğretmenlerin Mesleki Profesyonelliği Ölçeği Yılmaz ve Altınkurt (2014) tarafından öğretmenlerin mesleki profesyonellik düzeylerini belirlemek amacıyla geliştirilmiştir. 251 öğretmen ile yürütülen çalışmada yapılan faktör analizi sonucunda ölçeğin 24 maddeden ve 4 alt boyuttan oluştuğu tespit edilmiştir. Bu alt boyutlar; kişisel gelişim (5 madde), mesleki duyarlılık (5 madde), kuruma katkı ( 8 madde), duygusal emek ( 6 madde) şeklindedir. 
Yapılan geçerlik güvenirlik analizleri sonucuna göre; ölçeğin faktör yükleri 0.42-0.70 arasında değişmektedir. Ölçeğin geneli için iç tutarlılık katsayısı 0.90'dur. Ölçek beşli likert yapıda olup tüm maddeler; “1-kesinlikle katılmıyorum, 2-katılmıyorum, 3-orta derecede katılıyorum, 4-katılıyorum ve 5- kesinlikle katılıyorum" şeklinde puanlanmaktadır. Ölçeğin tümünden toplam puan elde edilebilmektedir. Bir faktörden ya da ölçeğin tümünden alınan puanların artması, öğretmenlerin mesleki profesyonellik düzeyinin yüksek olduğunu göstermektedir (Yılmaz ve Altınkurt, 2014).

\section{Verilerin Toplanması}

Araştırmanın İstanbul ilindeki okul öncesi eğitim kurumlarında görev yapmakta olan okul öncesi öğretmenleri ile yürütülebilmesi için İl Milli Eğitim Müdürlügü̈’nden gerekli izinler alınmıştır. Ölçeklerin uygulanması aşamasında okul idarecileri ve öğretmenler ile iletişime geçilerek uygulama için uygun gün ve saat belirlenmiştir. Uygun gün ve saatin belirlendiği okullara gidilerek öncelikle okul idarecileri ile görüşülmüştür. Ardından öğretmenlerle görüşülerek araştırmanın konusu ve amacı açıklanmıştır. Araştırmaya katılmak için gönüllü olan öğretmenlerden veri toplama araçlarını (Kişisel Bilgi Formu, Okul Öncesi Öğretmenleri için Sınıf Yönetimi Becerileri Ölçeği ve Öğretmenlerin Mesleki Profesyonelliği Ölçeği) cevaplandırmaları istenmiştir. Kişisel Bilgi Formu ve ölçeklerin yanıtlanma süresi yaklaşık 15 dakikadır. Yanıtlanan veri toplama araçları araştırmacı tarafından öğretmenlerden teslim alınmıştır.

Uygulamalar tamamlandıktan sonra tüm veri toplama araçları incelenmiş ve bu incelemeler sonucunda eksik bilgi içeren Kişisel Bilgi Formu ve ölçekler çözümlemeye dâhil edilmemiştir. Elde edilen veriler uygun istatistik paket programına aktarılarak gerekli çözümlemeler yapılmıştır.

\section{Verilerin Çözümlenmesi}

Araştırmada kullanılan veri toplama araçlarından elde edilen verilerin tümü istatistik paket programı kullanılarak çözümlenmiştir. Araştırmada grubun normal dağılım gösterip göstermediğini belirlemek amacıyla Kolmogorov-Smirnov testi yapılmış, test sonucunda grubun normal dağılım gösterdiği verilerde ( $p>.05)$ parametrik analizlerden, normal dağılım göstermediği $(p<.05)$ verilerde parametrik olmayan analizlerden yararlanılmıştır.

Okul öncesi öğretmenlerinin sınıf yönetimi becerileri ile mesleki profesyonellikleri arasındaki ilişki Pearson Çarpım Momentler Korelasyon Katsayısı analiz tekniği kullanılarak incelenmiştir.

Okul öncesi öğretmenlerinin sınıf yönetimi becerileri ile mesleki profesyonellikleri çeşitli değişkenlere göre incelenirken tanımlayıcı istatistikler (yüzde, frekans, ortalama ve standart sapma) ve fark testleri (t Test, Tek Yönlü Varyans Analizi (ANOVA), Kruskal Wallis-H Testi, Mann Whitney-U Testi ve Post Hoc Analizi) kullanılmıştır.

\section{BULGULAR}

Bu bölümde okul öncesi öğretmenlerinin sınıf yönetimi becerileri ile mesleki profesyonellikleri arasındaki ilişkiyi belirlemeye yönelik bulgular ve sınıf yönetimi becerileri ile mesleki profesyonelliklerinin çeşitli değişkenler açısından incelenmesine yönelik bulgulara alt amaçların sırası ile yer verilmiştir.

Tablo 2. Okul öncesi öğretmenlerinin sınıf yönetimi becerileri ve mesleki profesyonellikleri ile ilgili aritmetik ortalama ve standart sapma değerleri

\begin{tabular}{lccc}
\hline & N & $\bar{X}$ & Ss \\
\hline Sınıf Yönetimi Becerileri & 438 & 175,01 & 11,38 \\
Mesleki Profesyonellik & 438 & 98,62 & 8,17 \\
\hline
\end{tabular}

Toplam

Tablo 2'ye bakıldığında okul öncesi öğretmenlerinin sınıf yönetimi becerileri ile ilgili puan ortalamalarının 175,01, standart sapmanın 11,38; mesleki profesyonellik puan ortalamalarının 98,62, standart sapmanın 8,17 olduğu görülmektedir. Okul öncesi öğretmenlerinin sınıf yönetimi becerileri ve mesleki profesyonellik puan ortalamaları; ölçeklerden alınabilecek maksimum puana nisbeten yakın olduğu söylenebilir.

Tablo 3. Okul öncesi öğretmenlerinin sınıf yönetimi becerileri ile mesleki profesyonellikleri arasındaki ilişki ile ilgili pearson çarpım momentler korelasyon katsayısı sonuçları

\begin{tabular}{|c|c|c|c|}
\hline Değişkenler & $\mathrm{N}$ & r & $\mathrm{p}$ \\
\hline \multicolumn{4}{|l|}{ Sınıf Yönetimi } \\
\hline & 438 & ,479 & $.000 * * *$ \\
\hline Mesleki Profesyonellik & & & \\
\hline
\end{tabular}

$* * * p<.001$ 
Tablo 3'te görüldüğü üzere okul öncesi öğretmenlerinin sınıf yönetimi becerileri ile mesleki profesyonellikleri arasında orta düzeyde, pozitif yönlü ve anlamlı bir ilişki olduğu görülmektedir ( $p<.001, r=.479$ ). Köklü, Büyüköztürk ve Bökeoğlu (2006:94)'na göre, korelasyon katsayısının gücü; 0.01- 0.29 arasında ise düşük düzeyde ilişki, 0.30- 0.70 arasında ise orta düzeyde ilişki, 0.710.99 arasında ise yüksek düzeyde ilişki ve 1.00 ise mükemmel ilişki verilen aralıklarla belirlenebilmektedir. Buna göre okul öncesi öğretmenlerinin sınıf yönetimi becerileri arttıkça, mesleki profesyonelliklerinin de arttığı söylenebilir.

Tablo 4. Okul öncesi öğretmenlerinin sınıf yönetimi becerileri ve mesleki profesyonelliklerinin yaş değişkenine göre farklılaşma durumu ile ilgili yapılan tek yönlü varyans analizi (ANOVA) sonuçları

\begin{tabular}{|c|c|c|c|c|c|c|c|c|}
\hline & & & & Yaş & $\mathrm{N}$ & $\bar{X}$ & Ss & Anlamlı Fark \\
\hline \multirow{5}{*}{ Sınıf Yönetimi } & & & & $21-25$ & 116 & 170,81 & 12,23 & \\
\hline & & & & $26-30$ & 115 & 174,33 & 11,84 & $1-3$ \\
\hline & & & & $31-35$ & 100 & 177,31 & 10,48 & $1-4$ \\
\hline & & & & 36 ve üstü & 107 & 178,16 & 9,13 & $2-4$ \\
\hline & & & & Toplam & 438 & 175,01 & 11,38 & \\
\hline \multirow{6}{*}{$\begin{array}{l}\text { Mesleki } \\
\text { Profesyonellik }\end{array}$} & & & & $21-25$ & 116 & 96,98 & 8,51 & \\
\hline & & & & $26-30$ & 115 & 99,00 & 7,20 & \\
\hline & & & & $31-35$ & 100 & 98,29 & 8,93 & $1-4$ \\
\hline & & & & 36 ve üstü & 107 & 100,29 & 7,77 & \\
\hline & & & & Toplam & 438 & 98,62 & 8,17 & \\
\hline & Değişken & $\begin{array}{l}\text { Varyansın } \\
\text { Kaynağı }\end{array}$ & KT & SD & KO & $\mathrm{F}$ & $\mathrm{p}$ & \\
\hline \multirow{3}{*}{ Sınıf Yönetimi } & \multirow{3}{*}{ Yaş } & Gruplararası & 3695,255 & 3 & \multirow{3}{*}{$\begin{array}{c}1231,752 \\
121,921\end{array}$} & \multirow{3}{*}{10,103} & \multirow{3}{*}{$.000 * * *$} & \\
\hline & & Gruplariçi & 52913,633 & 434 & & & & \\
\hline & & & 56608,888 & 437 & & & & \\
\hline \multirow{3}{*}{$\begin{array}{l}\text { Mesleki } \\
\text { Profesyonellik }\end{array}$} & \multirow{3}{*}{ Yaş } & Gruplararası & 640,866 & 3 & \multirow{3}{*}{$\begin{array}{c}213,622 \\
65,820\end{array}$} & \multirow{3}{*}{3,246} & \multirow{3}{*}{$.022 *$} & \\
\hline & & Gruplariçi & 28565,977 & 434 & & & & \\
\hline & & Toplam & 29206,842 & 437 & & & & \\
\hline
\end{tabular}

$* p<.05 * * * p .001$

Tablo 4 incelendiğinde; okul öncesi öğretmenlerinin sınıf yönetimi becerileri $(F=10,103, p<.001)$ ve mesleki profesyonelliklerinin $(F=3,246, p<.05)$ yaş değişkenine göre anlamlı farklılık gösterdiği görülmektedir. Farklılıkların kaynağını belirlemek amacıyla yapılan post-hoc analizleri sonucunda; (sınıf yönetimi becerileri için Tamhane testi, mesleki profesyonellik için Scheffe testi) sınıf yönetimi becerileri açısından, 21-25 yaş aralığındaki öğretmenler ile 31-35 yaş aralığındaki öğretmenler arasında 31-35 yaş aralığındaki öğretmenler lehine, 21-25 yaş aralığındaki öğretmenler ile 36 ve üstü yaş aralığındaki öğretmenler arasında, 36 ve üstü yaş aralığındaki öğretmenler lehine, 26-30 yaş aralığındaki öğretmenler ile 36 ve üstü yaş aralığındaki öğretmenler arasında 36 ve üstü yaş aralığındaki öğretmenler lehine farklılık gözlenmiştir. Öğretmenlerin mesleki profesyonellikleri açısından, 21-25 yaş aralığındaki öğretmenler ile 36 ve üstü yaş aralığındaki öğretmenler arasında 36 ve üstü yaş aralığındaki öğretmenler lehine farklılık gözlenmiştir.

Tablo 5. Okul öncesi öğretmenlerinin sınıf yönetimi becerilerinin ve mesleki profesyonelliklerinin öğrenim durumu değişkenine göre farklılaşma durumu ile ilgili yapılan Kruskal Wallis-H testi sonuçları

\begin{tabular}{|c|c|c|c|c|c|c|c|}
\hline & Gruplar & $\mathrm{N}$ & $\begin{array}{c}\text { Sıralar } \\
\text { Ortalaması }\end{array}$ & $x^{2}$ & Sd & $p$ & Bonferroni \\
\hline \multirow{4}{*}{ Sınıf Yönetimi } & Ön lisans & 55 & \multirow{4}{*}{$\begin{array}{l}178,48 \\
223,72 \\
247,44\end{array}$} & \multirow{4}{*}{7,494} & \multirow{4}{*}{2} & \multirow{4}{*}{$.024 *$} & \multirow{4}{*}{$\begin{array}{l}1-2 \\
1-3\end{array}$} \\
\hline & Lisans & 356 & & & & & \\
\hline & Yüksek lisans & 27 & & & & & \\
\hline & Toplam & 438 & & & & & \\
\hline \multirow{4}{*}{$\begin{array}{l}\text { Mesleki } \\
\text { Profesyonellik }\end{array}$} & Ön lisans & 55 & \multirow{4}{*}{$\begin{array}{l}180,92 \\
221,71 \\
268,93\end{array}$} & \multirow{4}{*}{9,353} & \multirow{4}{*}{2} & \multirow{4}{*}{$.009 * *$} & \multirow{4}{*}{$1-3$} \\
\hline & Lisans & 356 & & & & & \\
\hline & Yüksek lisans & 27 & & & & & \\
\hline & Toplam & 438 & & & & & \\
\hline
\end{tabular}

${ }^{*} \mathrm{p}<.05 * * \mathrm{p}<.01$

| Kastamonu Eğitim Dergisi, 2020, Vol. 28, No. 4| 
Tablo 5’e bakıldığında okul öncesi öğretmenlerinin sınıf yönetimi becerileri $\left(x^{\wedge} 2=7,494 ;\right.$ sd=2; $\left.p<.05\right)$ ve mesleki profesyonellikleri $\left(x^{\wedge} 2=9,353 ; s d=2 ; p<.01\right)$ öğrenim durumu değişkenine göre farklılaşmaktadır. Araştırmada öğrenim durumu değişkeninde grup sayıları arasındaki farkın fazla olması, ikili karşılaştırmalarda hata payının artmasına yol açmaktadır. Bu nedenle Mann Whitney $U$ analizinde anlamlılık değeri için Bonferroni düzeltmesi (correction) yapılmıştır. Bonferroni düzeltmesi $p / k$, yani anlamlılık düzeyi / grup sayısı formülü ile belirlenmektedir (IFA, 2003; RCSE, 2003; Miller, 1991; Akt. Yüksel, 2004). Bu araştırma için anlamlılık düzeyi öğrenim durumu değişkenindeki grup sayısı üç olduğu için Bonferroni düzeltmesi ile 0.05/3=0.0166 olarak belirlenmiştir. Dolayısıyla Kruskal-Wallis $\mathrm{H}$ analizi sonrası öğrenim durumları arasındaki farkın test edilmesi için kullanılan MannWhitney $U$ testi için anlamlılık düzeyi $p=.0166$ olarak alınmıştır. Anlamlı farklııkları tespit etmek için yapılan Mann Whitney -U Testi sonucunda; sınıf yönetimi becerileri açısından, ön lisans mezunu öğretmenlerin ortalamaları, lisans ve yüksek lisans mezunu öğretmenlerin ortalamalarından düşük bulunmuştur. Mesleki profesyonellik açısından ise ön lisans mezunu öğretmenlerin ortalamaları, yüksek lisans mezunu öğretmenlerin ortalamalarından düşük bulunmuş, ön lisans mezunu öğretmenlerin ortalamaları ile lisans mezunu öğretmenlerin ortalamaları arasında farklılık tespit edilmemiştir. Lisans ve yüksek lisans mezunlarının sınıf yönetimi ve mesleki profesyonellik ortalamaları arasında da anlamlı farklılık tespit edilmemiştir.

Tablo 6. Okul öncesi öğretmenlerinin sınıf yönetimi becerileri ve mesleki profesyonelliklerinin mesleki kıdem değişkenine göre farklılaşma durumu ile ilgili yapılan tek yönlü varyans analizi (ANOVA) sonuçları

\begin{tabular}{|c|c|c|c|c|c|c|c|c|}
\hline & & & & Mesleki Kıdem & $N$ & $\bar{X}$ & Ss & $\begin{array}{c}\text { Anlamlı } \\
\text { Fark }\end{array}$ \\
\hline \multirow{5}{*}{ Sınıf Yönetimi } & & & & $0-5$ yıl & 163 & 172,34 & 12,24 & \multirow{5}{*}{$\begin{array}{l}1-3 \\
1-4\end{array}$} \\
\hline & & & & 6-10 yıl & 138 & 174,73 & 11,34 & \\
\hline & & & & $11-15$ yıl & 85 & 178,27 & 9,28 & \\
\hline & & & & 16 ve üstü yıl & 52 & 178,78 & 9,53 & \\
\hline & & & & Toplam & 438 & 175,01 & 11,38 & \\
\hline \multirow{5}{*}{$\begin{array}{l}\text { Mesleki } \\
\text { Profesyonellik }\end{array}$} & & & & $0-5$ yıl & 163 & 96,97 & 8,53 & \multirow{5}{*}{$\begin{array}{l}1-3 \\
1-4\end{array}$} \\
\hline & & & & 6-10 yıl & 138 & 97,93 & 8,33 & \\
\hline & & & & 11-15 yıl & 85 & 99,80 & 7,43 & \\
\hline & & & & 16 ve üstü yıl & 52 & 100,75 & 7,83 & \\
\hline & & & & Toplam & 438 & 98,62 & 8,17 & \\
\hline \multirow{4}{*}{ Sınıf Yönetimi } & Değişken & $\begin{array}{c}\text { Varyansın } \\
\text { Kaynağı }\end{array}$ & KT & SD & KO & $F$ & $p$ & \\
\hline & \multirow{3}{*}{$\begin{array}{l}\text { Mesleki } \\
\text { Kıdem }\end{array}$} & Gruplararası & 2809,762 & 3 & \multirow{3}{*}{$\begin{array}{l}936,587 \\
123,961\end{array}$} & \multirow{3}{*}{7,555} & \multirow{3}{*}{$.000 * * *$} & \\
\hline & & Gruplariçi & 53799,126 & 434 & & & & \\
\hline & & Toplam & 56608,888 & 437 & & & & \\
\hline \multirow{3}{*}{$\begin{array}{c}\text { Mesleki } \\
\text { Profesyonellik }\end{array}$} & \multirow{3}{*}{$\begin{array}{l}\text { Mesleki } \\
\text { Kıdem }\end{array}$} & Gruplararası & 807,458 & 3 & \multirow{3}{*}{$\begin{array}{c}269,153 \\
67,018\end{array}$} & \multirow{3}{*}{4,016} & \multirow{3}{*}{$.008^{* *}$} & \\
\hline & & Gruplariçi & 29085,665 & 434 & & & & \\
\hline & & Toplam & 29206,842 & 437 & & & & \\
\hline
\end{tabular}

$* * p<.01 * * * p<.001$

Tablo 6'da okul öncesi öğretmenlerinin sınıf yönetimi becerileri $(F=7,555, p<, 001)$ ve mesleki profesyonelliklerinin $(F=4,016$, $p<, 01)$ mesleki kıdem değişkenine göre anlamlı farklılık gösterdiği görülmektedir. Farklılıkların kaynağını belirlemek amacıyla yapılan post-hoc analizleri sonucunda; öğretmenlerin sınıf yönetimi becerileri ve mesleki profesyonelliklerinde mesleki kıdemi 05 yıl arasında olan öğretmenlerin ortalamaları, kıdemi 11-15 yıl arasında olan ve 16 ve üstü yıl kıdeme sahip öğretmenlerin ortalamalarına göre düşük bulunmuştur. Diğer kıdem yılları arasında anlamlı farklılığa rastlanmamıştır. 
Tablo 7. Okul öncesi öğretmenlerinin sınıf yönetimi becerileri ve mesleki profesyonelliklerinin sınıfta bulunan çocuk sayısı değişkenine göre farklılaşma durumu ile ilgili yapılan tek yönlü varyans analizi (ANOVA) Sonuçları

\begin{tabular}{|c|c|c|c|c|c|c|c|c|}
\hline & & & & Çocuk Sayısı & $\mathrm{N}$ & $\bar{X}$ & Ss & Anlamlı Fark \\
\hline \multirow{4}{*}{ Sınıf Yönetimi } & & & & 15 ve daha az & 102 & 172,40 & 12,67 & \multirow{4}{*}{$1-3$} \\
\hline & & & & $16-20$ & 220 & 174,92 & 11,52 & \\
\hline & & & & $21-25$ & 116 & 177,48 & 9,27 & \\
\hline & & & & Toplam & 438 & 175,01 & 11,38 & \\
\hline \multirow{4}{*}{\multicolumn{2}{|c|}{$\begin{array}{l}\text { Mesleki } \\
\text { Profesyonellik }\end{array}$}} & & & 15 ve daha az & 102 & 97,82 & 8,43 & \multirow{4}{*}{ Fark yok } \\
\hline & & & & $16-20$ & 220 & 98,86 & 8,40 & \\
\hline & & & & $21-25$ & 116 & 98,87 & 7,49 & \\
\hline & & & & Toplam & 438 & 98,62 & 8,17 & \\
\hline & Değişken & Varyansın Kaynağı & KT & SD & KO & $\mathrm{F}$ & $p$ & \\
\hline \multirow{3}{*}{ Sınıf Yönetimi } & \multirow{3}{*}{ Çocuk Sayısı } & Gruplararası & 1404,567 & 2 & \multirow{3}{*}{$\begin{array}{l}702,283 \\
126,906\end{array}$} & \multirow{3}{*}{5,534} & \multirow{3}{*}{$.004^{* *}$} & \\
\hline & & Gruplariçi & 55204,321 & 435 & & & & \\
\hline & & Toplam & 56608,888 & 437 & & & & \\
\hline \multirow{3}{*}{$\begin{array}{l}\text { Mesleki } \\
\text { Profesyonellik }\end{array}$} & \multirow{3}{*}{ Çocuk Sayısı } & Gruplararası & 85,050 & 2 & \multirow{3}{*}{$\begin{array}{l}42,525 \\
66,947\end{array}$} & \multirow{3}{*}{,635 } & \multirow{3}{*}{.530} & \\
\hline & & Gruplariçi & 29121,793 & 435 & & & & \\
\hline & & Toplam & 29206,842 & 437 & & & & \\
\hline
\end{tabular}

$* * p<.01$

Tablo 7'de okul öncesi öğretmenlerinin sınıf yönetimi becerileri ve mesleki profesyonellikleri sınıfta bulunan çocuk sayısı değişkenine göre incelenmiştir. Buna göre öğretmenlerin sınıf yönetimi becerileri, sınıfta bulunan çocuk sayısı değişkenine göre anlamlı düzeyde farklılaşmakta iken ( $F=5,534, p<.01)$, mesleki profesyonellikleri sınıfta bulunan çocuk sayısı değişkenine göre anlamlı düzeyde farklılaşmamaktadır. $(F=, 635, p>.05)$. Sınıf yönetimi becerileri için ortaya çıkan anlamlı farklıı̆̆ı tespit etmek amacıyla yapılan post-hoc analizi sonucu (Tamhane testi) söz konusu farklılık; sınıfında 15 ve daha az çocuk bulunan öğretmenler ile sınıfında 21-25 çocuk bulunan öğretmenler arasında, sınıfında 21-25 çocuk bulunan öğretmenler lehine bulunmuştur. Diğer çocuk sayısı grupları arasında anlamlı bir farklılığa rastlanmamıştır.

Tablo 8. Okul öncesi öğretmenlerinin sınıf yönetimi becerileri ve mesleki profesyonelliklerinin eğitim verilen yaş grubu değişkenine göre farklılaşma durumu ile ilgili yapılan tek yönlü varyans analizi (ANOVA) Sonuçları

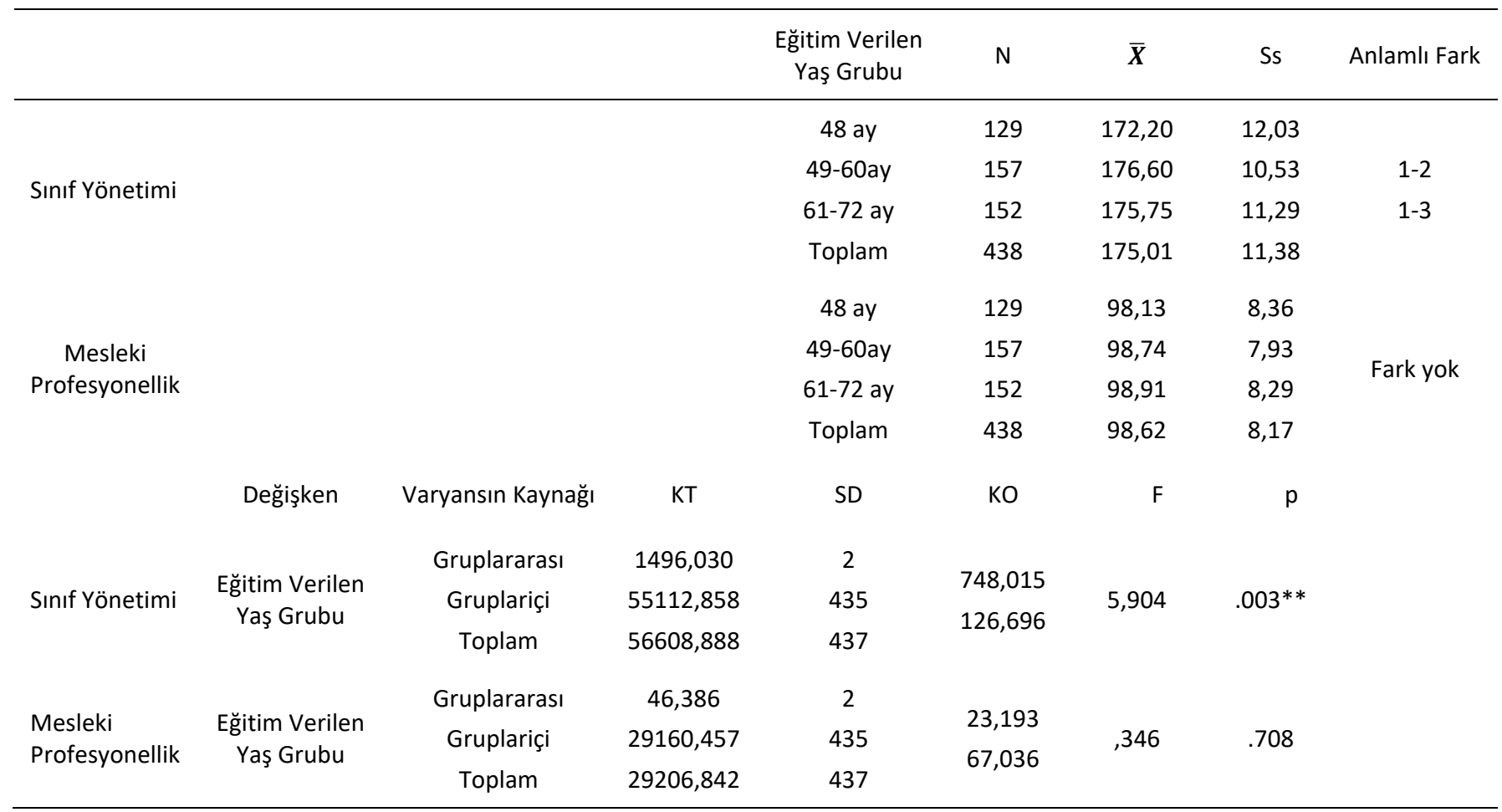

$* * p<.01$ 
Tablo 8'e bakıldığında, okul öncesi öğretmenlerinin sınıf yönetimi becerileri eğitim verilen yaş grubuna göre anlamlı farklılık gösterirken $(F=5,594, p<.01)$; mesleki profesyonellikleri eğitim verilen yaş grubuna göre anlamlı farklılık göstermemektedir. Sınıf yönetimi becerileri için ortaya çıkan anlamlı farklıığı tespit etmek amacıyla yapılan post-hoc analizi (Scheffe testi) sonucu söz konusu farklıık; 48 aylık yaş grubuyla çalışan öğretmenler ile 49-60 aylık yaş grubuyla çalışan öğretmenler arasında, 49-60 aylık yaş grubuyla çalışan öğretmenler lehine; 48 aylık yaş grubuyla çalışan öğretmenler ile 61-72 aylık yaş grubuyla çalışan öğretmenler arasında 61-72 aylık yaş grubuyla çalışan öğretmenler lehine bulunmuştur. Diğer yaş grupları arasında anlamlı farklıık olmadığı tespit edilmiştir.

\section{TARTIŞMA}

Araştırmada okul öncesi öğretmenlerinin sınıf yönetimi becerileri ve mesleki profesyonellikleri kendi algılarına göre incelenmiştir. Araştırma sonucuna göre okul öncesi öğretmenlerinin sınıf yönetimi becerileri puan ortalamaları ve mesleki profesyonellik puan ortalamaları, ölçeklerden alınabilecek maximum puana nispeten yakın bulunmuştur. Bu sonuçtan yola çıkılarak, öğretmenlerin kendilerini sınıf yönetimi ve mesleki profesyonellik açısından yeterli gördükleri söylenebilir.

Araştırma sonucuna benzer olarak okul öncesi öğretmenlerinin sınıf yönetimi becerilerinin yüksek düzeyde bulunduğu çalışmalar literatürde mevcuttur (Adıgüzel ve İpek, 2016; Sadık ve Dikici Sığırtmaç, 2016; Nur, 2012; Denizel Güven ve Cevher, 2005). Akan, Şener, Başar ve Şen (2016) ise araştırmalarında sınıf öğretmenlerinin sınıf yönetimi becerilerini okul yöneticisi görüşlerine göre incelemiş ve araştırma sonucunda okul müdürlerinin öğretmenlerin sınıf yönetimi becerilerini yeterli görmedikleri tespit edilmiştir. Yine Gangal (2013), Akgün, Yarar ve Dinçer (2011) araştırmalarında okul öncesi öğretmenlerin okul öncesi öğretmenlerinin sınıf yönetimi becerilerini gözlem yoluyla incelmiş ve öğretmenlerin sınıf yönetimi becerilerinin profesyonel tutumdan uzak olduğunu, olumsuz sınıf yönetimi stratejilerini kullandıklarını gözlemlemişlerdir. Bu araştırmalar çalışma sonucu ile benzerlik göstermemektedir. Çalışma sonucunda öğretmenlerin sınıf yönetimi beceri düzeyleri kendi algılarına göre yüksek çıkmıştır. Oysa bu durum uygulamalarında değişiklik gösterebilir. Bunun nedeni öğretmenlerin sınıf yönetiminde zorlansalar bile bunu yansıtmak istememeleri ya da ideal olanı bilseler bile uygulamaya gelince bunu gerçekleştirmemeleri olabilir. Nitekim yapılan çalışmalar incelendiğinde öğretmenlerin kendi algılarına göre sınıf yönetimi becerileri yüksek; gözlem sonuçlarına göre ise orta ve düşük düzeydedir. Bu nedenle öğretmenlere performanslarına yönelik geri bildirimde bulunulmasının, sınıf yönetimi becerilerini geliştirmelerine yardımcı olacağı düşünülmektedir.

Okul öncesi öğretmenlerinin mesleki profesyonelliklerinin değerlendirildiği çalışmalara rastlanmamakla birlikte mesleki yeterliklerinin incelendiği çalışmalar literatürde mevcuttur. Bu çalışmalarda okul öncesi öğretmenlerinin çoğunluğunun mesleki yeterlik konusunda kendilerini yeterli gördükleri sonucuna ulaşılmıştır (Kanbay-Ak, Yıldırım ve Kadıoğlu-Ateş, 2016; Bağ, 2015; Çabuk, 2014; Türkeç-Aktaş, 2012). Bu çalışmalar, araştırma sonucu ile benzerlik göstermektedir. Profesyonel öğretmen, çocukların eğitimde davranışlarını belli kurallar ve standartlara bağlamayan, çocukların en iyi şekilde eğitim almaları için gereken davranışları belirleyip uygulayabilen kişidir (Cerit, 2012). Bu bağlamda öğretmenlerin profesyonel davranış sergilemeleri önemlidir. Çünkü öğretmen profesyonelliği eğitimin niteliğini arttırmaktadır (Thoonen, Sleegers, Peetsma ve Geijsel, 2011).

Okul öncesi öğretmenlerinin sınıf yönetimi becerileri ile mesleki profesyonellikleri arasında orta düzeyde, pozitif yönlü ve anlamlı bir ilişki bulunmuştur. Yani okul öncesi öğretmenlerinin sınıf yönetimi becerileri arttıkça, mesleki profesyonellikleri de artmaktadır. Sınıf yönetiminin boyutlarında; fiziki ortamın düzenlenmesi, planlama ve programlama faaliyetlerinin yönetimi, zaman yönetimi, sınıf içindeki ilişkilerin yönetimi ve davranış yönetimi bulunmaktadır (Çalık, 2012). Bu boyutlar aynı zamanda öğretmen profesyonelliğini kapsamaktadır. Nitekim Peterson vd., (2016), öğretmenlerin profesyonelliğini; etkileşim, aile katılımı, eğitimin planlanması ve çocukların gelişiminin değerlendirilmesi, öğretim stratejilerinin kullanılması, mesleki gelişimin desteklenmesi, büyüme ortamı yaratılması ve değerlerin geliştirilmesi olarak yedi süreçle tanımlamışlardır. Bu nedenle sınıf yönetimi becerisi ile mesleki profesyonellik arasında ilişki olduğu düşünülmektedir. Avrupa Komisyonu ve OECD tarafından yayınlanan raporlarda, okul öncesi öğretmenlerinin profesyonelliği, erken çocukluk eğitiminin kalitesini sağlamada kilit bir faktör olarak belirtilmiştir. (Akt. Peterson vd.,2016).

Okul öncesi öğretmenlerinin sınıf yönetimi becerileri ve mesleki profesyonellikleri yaş arttıkça artmaktadır. Okul öncesi öğretmenlerinin sınıf yönetimi becerilerinin yaşa göre farklılaştığı çalışmalar literatürde mevcuttur. Bu çalışmalarda okul öncesi öğretmenlerinin sınıf yönetimi becerilerinin yaş arttıkça arttığı sonucuna ulaşılmıştır (Metin, Aydoğan, Kavak ve Mercan, 2017; Yıldırım, 2016; Dinçer ve Akgün, 2015). Bu sonuçlar araştırma sonucunu desteklemektedir. Okul öncesi öğretmenlerinin sınıf yönetimi becerilerinin yaş değişkenine göre farklılaşmadığı çalışmalar da literatürde mevcuttur (Yaşar-Ekici, Günhan ve Anılan,2016; Nur, 2012). Farklı araştırmacılar tarafından farklı sonuçlara ulaşıması yaş değişkeni ile kıdem değişkeninin bağlantılı olabileceği düşüncesini akla getirmektedir. Yani yaş arttıkça kıdem de artar. Yaşı büyük olan öğretmenlerin sınıf yönetimi becerilerinin yüksek olması, kıdemlerinin getirdiği tecrübeden kaynaklanıyor olabilir. Nitekim yaş arttıkça sınıf yönetimi becerilerinin arttığı çalışmalarda da yaş ile kıdem değişkeninin bağlantılı olduğu ve bu nedenle sınıf yönetimi becerilerinin yaşa bağlı olarak farklılaştığı dile getirilmiştir.

Okul öncesi öğretmenlerin mesleki profesyonellikleri ile yaş değişkeninin incelendiği bir araştırmaya rastlanmamıştır. Benzer olarak Bağ (2015) tarafından yapılan araştırmada okul öncesi öğretmenlerinin öğretmen yeterlikleri ve hizmet içi eğitim ihtiyaçları yönetici ve öğretmen görüşleriyle incelenmiştir. Araştırma sonucunda yöneticilerin \%85'i öğretmenlerin yaşı arttıkça meslekte daha yeterli olduklarını düşündüklerini ancak bunun öğretmenin kendini yenileme davranışıyla birlikte gelişebileceğini belirtmişlerdir. Araştırma sonucundan farklı olarak Şahin (2010); okul öncesi öğretmenlerinin mesleğe yönelik tutumları ve 
yeterlilik algılarını incelediği araştırmasının sonucunda, yaş değişkenine göre öğretmenlerin mesleki yeterlik algılarının farklılaşmadığı sonucuna ulaşmıştır. Türkiye'de okul öncesi öğretmenlerinin mesleki profesyonelliklerinin yaş değişkeni ile olan ilişkisinin incelendiği çalışmaların sınırlı olması, seçilen örneklemlerin ve kullanılan ölçme araçlarının farklı olması gibi etkenlerin de bulunması çıkan sonucun yorumlanmasını etkilemektedir. Bu nedenle okul öncesi öğretmenlerinin mesleki profesyonelliklerinin demografik özelliklere göre incelendiği araştırmalara ihtiyaç duyulmaktadır.

Okul öncesi öğretmenlerinin sınıf yönetimi becerileri ve mesleki profesyonellikleri öğrenim durumu yükseldikçe artmaktadır. Araştırma sonucuna benzer olarak öğretmenlerin sınıf yönetimi becerilerinin öğrenim durumuna göre farklılaştığı çalışmalar mevcutken (Ata ve Akman, 2016; Toran ve Gençgel Akkuş, 2016), araştırma sonucundan farklı çalışmalar da bulunmaktadır (Yaşar Ekici, Günhan ve Anılan, 2017; Zembat, Tunçeli ve Akşin Yavuz, 2017; Sadık ve Dikici-Sığırtmaç, 2016; Semerci, 2015; Nur, 2012). Lisans ve lisansüstü mezuniyete sahip öğretmenler; öğrenim süreleri boyunca uygulama yapabilmekte, yüz yüze etkileşim kurabilmekte ve geri bildirim alabilmektedir. Ön lisans mezunu öğretmenlerin ise uygulama yapma, yüz yüze etkileşim kurma ve geri bildirim alma olanakları sınırlıdır. Bu nedenle de sınıf yönetimi becerilerinin lisans ve lisansüstü bireylere göre düşük olması olası bir durum olarak görülebilir.

Okul öncesi öğretmenlerin mesleki profesyonellikleri ile öğrenim durumu değişkeninin incelendiği bir araştırmaya rastlanmamıştır. Benzer olarak, Bağ (2015) tarafından yürütülen araştırma sonucunda yöneticilerin çoğunluğu yüksek lisans mezunu öğretmenlerin daha yeterli olduğunu düşündüklerini belirtmişlerdir. Araştırma sonucunda ayrıca eğitim süresindeki artışın öğretmen yeterliklerine yansıdığı sonucuna ulaşılmıştır. Türkeç-Aktaş (2012) ise okul öncesi öğretmenlerinin yeterlilik düzeylerini incelediği araştırmasının sonucunda mezun olunan okul değişkeninin öğretmenlerin yeterlik alanlarını etkilemediği sonucuna ulaşmıştır. Yine Şahin (2010); okul öncesi öğretmenlerinin en son mezun olunan okul türü değişkenine göre mesleki yeterlik algılarının farklılaşmadığı sonucuna ulaşmıştır. Teltik (2009) ise araştırmasının sonucunda öğrenim durumu değişkeni için ön lisans mezunu öğretmenlerin lisans mezunu öğretmenlere oranla daha yüksek mesleki yeterlilik düzeyine sahip olduklarını tespit etmiştir. Bu sonuçlar araştırma sonuçları ile benzerlik göstermemektedir. Profesyonelliğin ölçütlerine baktığımızda temelde elde edilmiş bilgi kriteri karşımıza çıkmaktadır (Flexner, 2001). Bu bilgilerin de öğrenim düzeyi ile doğru orantılı olarak artacağı düşünülebilir. Ayrıca yine ön lisans mezunu bireylerin eğitim sürecinde yüz yüze etkileşim kurma, uygulama yapma ve geri bildirim alma şanslarının düşük olması da mesleklerini profesyonelce yürütmelerini olumsuz yönde etkiliyor olabilir. Bu nedenle araştırma sonucunda öğrenim durumundaki artış mesleki profesyonelliği olumlu yönde etkilemiş olabilir.

Okul öncesi öğretmenlerinin sınıf yönetimi becerileri ve mesleki profesyonellikleri kıdem seviyesi arttıkça artmaktadır. Öğretmenlerin sınıf yönetimi becerilerinin mesleki kıdem değişkenine göre farklılaştığı çalışmalar mevcuttur (Yaşar Ekici, Günhan ve Anılan, 2017; Sadık ve Dikici Sığırtmaç, 2016; Yıldırım, 2016; Dinçer ve Akgün, 2015; Semerci, 2015). Kıdeme göre farklılaşmanın bulunmadığı çalışmalar da mevcuttur (Adıgüzel ve İpek, 2016; Keleş, 2013). Kıdemin artması sonucu sınıf yönetimi becerilerinin de artmasının yaşla ve deneyim ile alakalı olduğu düşünülmektedir. Yaş ile gelen tecrübe sonucu elde edilen kıdem sınıf yönetimi becerisini de olumlu yönde etkilemiş olabilir. Deneyim öğretmenlerin öğretimi etkileyen faktörlerin bilincine varma, teori ve pratiği harmanlama becerileri geliştirmekte, değişikliklere adapte olmalarını kolaylaştırmaktadır (Taggart ve Wilson, 2005; Rodgers, 2001). Fakat sınıf yönetimi becerilerinde deneyimin tek başına yeterli olamayacağı ve bu nedenle de öğretmenlerin kişilik özellikleri, içinde bulundukları çevre, görev yapılan kurumun kültürü, görev yaptıkları bölge koşulları, veliler ile kurulan ilişkiler gibi faktörlerin de ele alındığı çalışmaların yapılması gerektiği düşünülmektedir.

Okul öncesi öğretmenlerinin mesleki profesyonelliklerinin kıdem değişkenine göre farklılaştığı çalışmaya rastlanmamıştır. Okul öncesi öğretmenlerinin mesleki yeterliliklerinin incelendiği araştırmalara bakıldığında; kıdem arttıkça mesleki yeterliğin arttığı sonucuna ulaşılmıştır (Bağ, 2015; Çabuk, 2014). Bu çalışmalar araştırma sonucu ile benzerlik göstermektedir. Teltik (2009) ise okul öncesi öğretmenlerinin mesleki yeterlik algılarının kıdem değişkenine göre farklılaşmadığı sonucuna ulaşmıştır. Farklı araştırmacılar tarafından farklı sonuçlara ulaşımasının nedeni kıdem değişkeninin mesleki profesyonelliği doğrudan etkilememesi olabilir. Nitekim Yılmaz ve Altınkurt (2015) mesleki kıdem değişkeninin mesleki profesyonelliği doğrudan değil; parabolik etkilediğini ifade etmektedir. Başka bir değişle, mesleğin başında öğretmenler belli bir heyecan ve motivasyon ile mesleklerini profesyonelce yürütürler. Yıllar geçtikçe ve sistemin içine girdikçe öğretmenlerin heyecan ve motivasyonları azalmakta; mesleğin sonlarına doğru da sakinlik ve kendine güvenin artmasıyla profesyonelliklerinin de arttığı görüşündedirler. Bu nedenle de çalışmada mesleki kıdemi fazla olan öğretmelerin mesleki profesyonellikleri diğer kıdem gruplarına göre yüksek çıkmış olabilir.

Okul öncesi öğretmenlerinin sınıf yönetimi becerileri sınıfta bulunan çocuk sayısı değişkenine göre farklılaşırken, mesleki profesyonellikleri farklılaşmamaktadır. Dinçer ve Akgün (2015) araştırmaya benzer olarak, okul öncesi öğretmenlerinin sınıf yönetimi becerilerinin sınıfta bulunan çocuk sayısına göre farklılaştığı sonucuna ulaşmışlardır. Araştırma sonucundan farklı olarak Semerci (2015), araştırmasında sınıfında 11-15 çocuk bulunan okul öncesi öğretmenlerinin sınıf yönetimi becerilerinin, sınıfında 16-20 çocuk olan öğretmenlere göre daha yüksek olduğu sonucuna ulaşmıştır. Yine Yaşar Ekici, Günhan ve Anılan (2017), Adıgüzel ve İpek (2016), Toran ve Gençgel-Akkuş (2016), Nur (2012), Denizel-Güven ve Cevher (2005) ise öğretmenlerin sınıf yönetimi becerilerinin sınıfta bulunan çocuk sayısı değişkenine göre farkııık göstermediği sonucuna ulaşmışlardır. Bu çalışmalar araştırma sonucu ile benzerlik göstermemektedir.

Mesleki profesyonellik ise araştırmaya benzer olarak bir çalışmada (Çelik ve Yılmaz, 2015) okuldaki toplam öğrenci sayısına göre incelenmiş ve çalışma sonucunda okuldaki öğrenci sayısına göre mesleki profesyonelliğin farklılaşmadığı tespit edilmiştir. Öğretmenler için profesyonellik daha çok bireysel faktörlerden etkilenir. Bunlar; öğretmenlerin yeterliklerine, yaptıkları işe karşı

| Kastamonu Eğitim Dergisi, 2020, Vol. 28, No. 4| 
olan tutumlarına ve mesleki bağlılık düzeyine, diğer öğretmenlerle, yönetimle ve öğrencilerle olan ilişkilerine bağlıdır (Yirci, 2017). Dolayısıyla sınıfta bulunan çocuk sayısına göre öğretmenlerin mesleki profesyonellikleri farklılaşmamış olabilir.

Okul öncesi öğretmenlerinin sınıf yönetimi becerileri eğitim verilen yaş grubu değişkenine göre farklılaşırken, mesleki profesyonellikleri farklılaşmamaktadır. Dinçer ve Akgün (2015) okul öncesi öğretmenlerinin sınıf yönetimi becerilerinin eğitim verilen yaş grubu değişkenine göre araştırmayla örtüşen sonuçlara ulaşmışken; Toran ve Gençgel Akkuş (2016), Nur (2012) sınıf yönetimi becerileri ile eğitim verilen yaş grubu arasında anlamlı farka rastlamamışlardır.

Okul öncesi öğretmenlerinin mesleki profesyonelliklerinin eğitim verilen yaş grubu değişkenine göre farklılaşma durumunun incelendiği araştırmaya rastlanmamıştır. Araştırma sonucuna benzer olarak Teltik (2009), araştırmasında okul öncesi öğretmenlerinin mesleki yeterlik algılarının eğitim verilen yaş grubu değişkenine göre anlamlı farklılık göstermediği sonucuna ulaşmıştır.

\section{SONUÇ VE ÖNERILER}

Özetle bu araştırmanın sonucunda; okul öncesi öğretmenlerinin sınıf yönetimi becerileri ile mesleki profesyonelliklerinin yüksek düzeyde olduğu tespit edilmiştir. Okul öncesi öğretmenlerinin sınıf yönetimi becerileri ile mesleki profesyonellikleri arasında orta düzeyde, pozitif yönlü ve anlamlı bir ilişki olduğu bulunmuştur. Ayrıca okul öncesi öğretmenlerinin sınıf yönetimi becerilerinin yaş, eğitim durumu, mesleki kıdem, sınıftaki çocuk sayısı ve eğitim verilen yaş grubu değişkenlerine göre anlamlı düzeyde farklılaştığı tespit edilmiştir. Okul öncesi öğretmenlerinin mesleki profesyonelliklerinin yaş, eğitim durumu ve mesleki kıdem değişkenlerine göre anlamlı olarak farklılaştığı sonucuna ulaşıımıştır. Araştırma sonuçlarından hareketle aşağıda belirtilen öneriler sunulmuştur.

\section{Araştırmacılara Yönelik Öneriler}

- Araştırma İstanbul ili ile sınırlı olduğundan; okul öncesi öğretmenlerinin sınıf yönetimi becerileri ile mesleki profesyonellikleri tüm Türkiye için incelenebileceği gibi farklı illerde de yapılabilir.

- Araştırmada okul öncesi öğretmenlerinin kendi algılarına göre sınıf yönetimi becerileri ve mesleki profesyonellikleri incelenmiştir. Öğretmenlerin sınıf yönetimi becerileri ve mesleki profesyonellikleri, veli ve yönetici görüşlerine göre incelenebilir.

- Araştırma nicel yöntemle yürütülmüş olup, araştırmada okul öncesi öğretmenlerinin kendi algılarına göre sınıf yönetimi becerileri ve mesleki profesyonellikleri incelenmiştir. Okul öncesi öğretmenlerinin sınıf yönetimi becerileri ve mesleki profesyonellik düzeyleri, nitel yöntemle de (gözlem, görüşme vb.) desteklenerek karşılaştırmalar yapılabilir.

\section{Kurum ve Kuruluşlara Yönelik Öneriler}

- Araştırma sonucunda okul öncesi öğretmenlerinin sınıf yönetimi becerileri ile mesleki profesyonellikleri arasında orta düzeyde pozitif yönlü ve anlamlı bir ilişki bulunması sonucundan hareketle; okul öncesi öğretmenlerinin sınıf yönetimi becerilerinin geliştirilmesi adına lisans eğitiminde öğretmen adayların eğitiminden başlanarak adımlar atılması, öğretmenlerin de görevleri süresince sınıf yönetimi becerilerini destekleyen seminer, atölye çalışmaları, vb. faaliyetlerle desteklenmeleri önerilmektedir.

- Araştırma sonucuna göre mesleki kıdem değişkeni hem sınıf yönetimi becerilerini hem de mesleki profesyonellik düzeyini olumlu yönde etkilemektedir. Kıdemi fazla olan öğretmenlerin göreve yeni başlayan tecrübesiz öğretmenlere deneyimlerini aktarabileceği, öğretmenlerin birbirleriyle bilgi ve birikimlerini kurum içinde paylaşabilecekleri ortamlar, yönetim tarafından oluşturulabilir.

\section{KAYNAKÇA}

Addie, K. L. (2005). Proficiency-based standards reform: Implications for teacher professionalism and accountability (Unpublished doctoral dissertation), University of Oregon, Oregon, USA.

Adıgüzel, í. \& İpek, C. (2016). Okul öncesi öğretmenlerinin sınıf yönetimi becerileri ve tükenmişlik düzeyleri. International Journal of Eurasia Social Sciences, 7(23), 247-273.

Adıgüzel, O., Tanrıverdi, H., \& Sönmez-Özkan, D. (2011). Mesleki profesyonellik ve bir meslek mensupları olarak hemşireler örneği. Yönetim Bilimleri Dergisi, 9(2), 237-259.

Akan, D., Şener, N., Başar, M., \& Şen, B. (2016). Öğretmenlerin sınıf yönetimi becerilerinin okul yöneticisi görüşlerine göre değerlendirilmesi. Uşak Üniversitesi Eğitim Araştırmaları Dergisi, 2(1), 71-88.

Akar, H., Tantekin Erden, F., Tor, D., \& Şahin, İ.T. (2010). Öğretmenlerin sınıf yönetimi yaklaşımları ve deneyimlerinin incelenmesi. Ilkoğretim Online, 9(2), 792-806.

Akgün, E., Yarar, M., \& Dinçer, Ç. (2011). Okul öncesi öğretmenlerin sınıf içi etkinliklerde kullandıkları sınıf yönetimi stratejilerinin incelenmesi. Pegem Ĕgitim ve Öğretim Dergisi, 1(3), 1-9.

Alatlı, R. (2014). Genel ve özel eğitim öğretmenlerinin sınıf yönetimi bilgileri ile sınıf yönetimine ilişkin öz yetkinliklerinin karşılaştırılması. Yayımlanmamış Yüksek Lisans Tezi. Ankara Üniversitesi Eğitim Bilimleri Enstitüsü, Ankara. 
Alkan, H. B. (2007). ilköğretim öğretmenlerinin istenmeyen davranışlarla baş etme yöntemleri ve okulda şiddet. Yayımlanmamış Yüksek Lisans Tezi, Niğde Üniversitesi Sosyal Bilimler Enstitüsü, Niğde.

Altan, M.Z. (2017). Profesyonel öğretmenliğe doğru. (5. Baskı). Ankara: Pegem Akademi Yayıncılık.

Altınkurt Y., \& Yılmaz, K. (2014). Öğretmenlerin mesleki profesyonelliği ile iş doyumları arasındaki ilişki. Sakarya University Journal of Education, 4(2), 57-71.

Ata, S., \& Akman, B. (2016). Bağlanma boyutları, sınıf yönetimi profilleri ve öğretmen-aile arasındaki ilişkilerin incelenmesi. ilköğretim Online, 15(3), 820-837.

Bağ, C. (2015). Okul öncesi öğretmenlerinin öğretmen yeterlikleri ve hizmet içi eğitim ihtiyaçları (Yayımlanmamış yüksek lisans tezi). Düzce Üniversitesi Sosyal Bilimler Enstitüsü, Düzce.

Başar, H. (1999). Sınıf yönetimi. Ankara: Milli Eğitim Bakanlığı Yayınları Öğretmen Kitapları Dizisi:200.

Bayhan, G. (2011). Öğretmenlerin profesyonelliğinin incelenmesi. Yayımlanmamış Doktora Tezi. Marmara Üniversitesi Eğitim Bilimleri Enstitüsü, istanbul.

Cerit, Y. (2012). Okulun bürokratik yapısı ile sınıf öğretmenlerinin profesyonel davranışları arasındaki ilişki. Kuram ve Uygulamada Eğitim Yönetimi, 18(4), 497-521.

Çabuk, B. (2014). Anasınıfı ve sınıf öğretmenlerinin okuma yazmaya hazırlık etkinlikleriyle ilgili algı ve bilgi düzeyleriyle mesleki yeterliklerine ilişkin algı düzeylerinin karşılaştııılması (Yayımlanmamış doktora tezi). Gazi Üniversitesi Eğitim Bilimleri Enstitüsü, Ankara.

Çalık, T. (2012). Sınıf yönetimiyle ilgili temel kavramlar. L.Küçükahmet, (Ed.), Sınıf yönetimi içinde (s.1-16). (13. Baskı). Ankara: Pegem Akademi Yayınları.

Çelik M., \& Yılmaz, K. (2015). Öğretmenlerin mesleki profesyonelliği ile tükenmişlikleri arasındaki ilişki. Sakarya Üniversitesi Eğitim Fakültesi Dergisi, 30, 102-131.

Çelik-Yılmaz, D. (2017). Mesleki profesyonellik ile öğretmen liderliğine yönelik öğretmen algıları arasındaki ilişki. Yayımlanmamış Yüksek Lisans Tezi. Abant İzzet Baysal Üniversitesi Eğitim Bilimleri Enstitüsü, Bolu.

Demir, T. (2015). Okulöncesi öğretmenlerinin öz-yeterlik algılarının ve sınıf yönetimi stratejilerinin çocuk- öğretmen ilişkileri üzerindeki etkileri. Yayımlanmamış Yüksek Lisans Tezi. Ege Üniversitesi Sosyal Bilimler Enstitüsü, İzmir.

Demirel, Ö. (2006). Öğretimde planlama ve değerlendirme öğretme sanatı. (10. Baskı). Ankara: Pegem Akademi Yayınları.

Demirkasımoğlu, N. (2010). Defining "teacher professionalism" from different perspectives. Procedia Social and Behavioral Sciences, 9, 20472051.

Denizel Güven, E., \& Cevher, F. N. (2005). Okul öncesi öğretmenlerinin sınıf yönetimi becerilerinin çeşitli değişkenler açısından incelenmesi. Pamukkale Üniversitesi Eğitim Fakültesi Dergisi, 18(2), 1-22.

Denkdemir, E. (2007). Sınıf öğretmenlerinin sınıf yönetimi hakkında görüşleri ve bir uygulama. Yayımlanmamış Yüksek Lisans Tezi, Beykent Üniversitesi Sosyal Bilimler Enstitüsü, İstanbul.

Dinçer, Ç., Deniz, K.Z., Akgün, E., \& Ulubey, Ö. (2018). Sınıf yönetiminde öğretmen stratejileri envanterinin Türk kültürüne uyarlanması. Mersin Üniversitesi Eğitim Fakültesi Dergisi, 2018; 14(1), 355-371.

Dinçer, Ç., \& Akgün, E. (2015). Okul öncesi öğretmenleri için sınıf yönetimi becerileri ölçeğinin geliştirilmesi ve öğretmenlerin sınıf yönetimi becerilerinin çeşitli değişkenlerle ilişkisi. Eğitim ve Bilim, 40(177), 187-201.

Erden, M. (2005). Sınıf yönetimi. (1.Baskı). İstanbul: Epsilon Yayıncılık.

Flexner A. (2001). Is social work a profession? Version of record. Research on Social Work Practice. 11(2), 152-165.

Gangal, M. (2013). Okul öncesi eğitim öğretmenlerinin sınıfta istenmeyen davranışlarla başa çıkmaya yönelik uygulamaları ve sınıf yönetimi stratejileri hakkındaki inançlarının incelenmesi, Yayımlanmamış yüksek lisans tezi. Karadeniz Teknik Üniversitesi Eğitim Bilimleri Enstitüsü, Trabzon.

Gökçora, í. H. (2005). Toplumsal yaşamımızda ve Türk bilim-dünyasında profesyonel ve profesyonellik kavramlarına değin. Bilgi Dünyası, 6(2), 237-250.

Güven, D. (2010). Profesyonel bir meslek olarak Türkiye'de öğretmenlik. Boğaziçi Üniversitesi Eğitim Dergisi, 27(2), 13-21.

Hargreave, A., \& Goodson, I. F. (1996). Teachers' professional lives: Aspirations and actualities. In I. F. Goodson, \& A. Hargreaves (Eds.), Teachers professional lives (pp. 1-27). London: Farmer Press.

İlgan, A., Aslanargün, E., \& Shaukat, S. (2015). Öğretmenlik mesleği profesyonellik ölçeği geçerlik ve güvenirlik çalışması. Eğitimde Kuram ve Uygulama, 11(4), 1454-1474.

Kagan, D. M. (1992). Professional growth among pre-service and beginning teachers. Review of Education Research, 62(2), $129-169$.

Kanbay-Ak, G., Yıldırım, B., \& Kadıoğlu-Ateş H. (2016). Okul öncesi öğretmenlerinin mesleki yeterlilik algılarının incelenmesi (Başakşehir ilçesi örneği). Akademik Bakış Uluslararası Hakemli Sosyal Bilimler Dergisi, (55), 89-108.

Karaman, S.Z. (2016). Öğretmenlerin sınıf yönetimi yeterlikleri ile mesleki profesyonellikleri arasındaki ilişki (Yayımlanmamış yüksek lisans tezi). Yeditepe Üniversitesi Sosyal Bilimler Enstitüsü, İstanbul.

Karaman, S.Z. (2016). Öğretmenlerin sınıf yönetimi yeterlikleri ile mesleki profesyonellikleri arasındaki ilişki. Yayımlanmamış Yüksek Lisans Tezi. Yeditepe Üniversitesi Sosyal Bilimler Enstitüsü, İstanbul.

Karasar, N. (2016). Bilimsel araştırma yöntemleri. Ankara: Nobel Akademik Yayıncılık.

Kayabaşı, Y. (2009). Sınıf yönetimi kavramının sınıfta disiplin sağlamadan farklı yanları ve temel özellikleri. İçinde L. Küçükahmet (Editör). Sınıf yönetimi. (s. 58-79). (10. Baskı). Ankara: Pegem Akademi Yayınları. 
Keleş, O. (2013). Okul öncesi öğretmen adaylarının ve okul öncesi öğretmenlerinin sınıf yönetimine ilişkin tutum ve inançlarının incelenmesi. Yayımlanmamış yüksek lisans tezi. Çukurova Üniversitesi Sosyal Bilimler Enstitüsü, Adana.

Köklü, N., Büyüköztürk Ş., \& Bökeoğlu, Ö.ç. (2006). Sosyal bilimler için istatistik. Ankara: Pegem-A Yayıncılık.

Metin, Ş., Aydoğan, Y., Kavak, Ş. \& Mercan, Z. (2017). Effects of classroom management profiles of pre-school teachers on social skills and problem behaviors of children. Journal of Current Researches on Social Sciences (JoCReSS) 7(1), 517-534.

Millî Eğitim Bakanlığı (2017a). Öğretmenlik Mesleği Genel Yeterlikleri. Erişim Adresi: https://oygm.meb.gov.tr/meb_iys_dosyalar/2017_12/11115355_YYRETMENLYK_MESLEYY_GENEL_YETERLYKLERY.pdf.

Millî Eğitim Bakanlığı (2017b). Ilköğretim Özel Alan Yeterlikleri. Erişim Adresi: https://oygm.meb.gov.tr/www/ilkogretim-ozel-alanyeterlikleri/icerik/257.

Nur, i. (2012). Anaokullarında örgüt iklimi ile öğretmenlerin sınıf yönetimi becerileri arasındaki ilişkinin incelenmesi (Malatya ili örneği). Yayımlanmamış yüksek lisans tezi. İnönü Üniversitesi Eğitim Bilimleri Enstitüsü, Malatya.

Peterson, T., Veisson, M., Hujala, E., Härkönen, U., Sandberg, A., Johansson, I. \& Kovacsne Bakosi, E. (2016) Professionalism of preschool teachers in Estonia, Finland, Sweden and Hungary. European Early Childhood Education Research Journal, 24(1), 136- 156.

Phelps, P. H. (2003). Teacher professionalism. Kappa Delta Pi Record, 40(1), 7-11.

Rodgers, C. (2002). Defining reflection: Another look at John Dewey and reflective thinking. Teachers College Record, 104(4), 842-866.

Sadık, F., \& Dikici Sığırtmaç, A. (2016). Okul öncesi öğretmenlerinin sınıf yönetim becerileri ve uygulamalarına yönelik görüşlerinin incelenmesi. International Periodical for the Languages, Literature and History of Turkish or Turkic 11(14), 631-664.

Sarı, K. (2016). Okul öncesi öğretmenlerinin çocuk sevgilerinin ve mesleki benlik saygılarının profesyonellik değişkenleri açısından incelenmesi. Yayımlanmamış Yüksek Lisans Tezi. Necmettin Erbakan Üniversitesi Eğitim Bilimleri Enstitüsü, Konya.

Semerci, D. (2015). Okul öncesi ögrretmenlerinin sınıf yönetimi becerileri, öz yeterlik algıları ve mesleki motivasyonları arasındaki ilişkinin incelenmesi (Yayımlanmamış yüksek lisans tezi). Marmara Üniversitesi Eğitim Bilimleri Enstitüsü, İstanbul.

Strike, K. A. (1990). Is teaching a profession: how would we know? Journal of Personnel Evaluation in Education, 4, 91-117.

Sugai, G., \& Horner, R.H. (2002). The evolution of discipline practices: School-wide positive behavior supports. Child \& Family Behavior Therapy, 24(1), 23-50.

Şahin, S. Z. (2010). Okul öncesi eğitim öğretmenlerinin mesleğe yönelik tutumları ve yeterlilik algılarının bazı değişkenler açısından incelenmesi (Yayımlanmamış yüksek lisans tezi). Selçuk Üniversitesi Sosyal Bilimler Enstitüsü, Konya.

Taggart, G. L., \& Willson, A. P. (2005). Promoting reflective thinking in teachers in 50 action strategies. USA: Corwin Press.

Teltik, H. (2009). Okul öncesi öğretmenlerinin mesleki yeterlilik algılarının iş doyumu ve tükenmişlik düzeyleriyle ilişkisinin belirlenmesi (Yayımlanmamış yüksek lisans tezi). Marmara Üniversitesi Ĕgitim Bilimleri Enstitüsü, İstanbul.

Thoonen, E. E., Sleegers, P. J., Oort, F. J., Peetsma, T. T., \& Geijsel, F. P. (2011). How to improve teaching practices: The role of teacher motivation, organizational factors, and leadership practices. Educational Administration Quarterly, 47(3), 496-536.

Toran, M., \& Gençgel-Akkuş, H. (2016). Okul öncesi öğretmenlerinin sınıf yönetimi becerilerinin değerlendirilmesi: KKTC örneği. Kastamonu Eğitim, 24(4), 2041-2056.

Türkeç-Aktaş, Y. (2012). Okul öncesi öğretmenlerinin yeterlilik düzeyleri (Yayımlanmamış yüksek lisans tezi). Adnan Menderes Üniversitesi Sosyal Bilimler Enstitüsü, Aydın.

Yaşar-Ekici, F., Günhan, G., \& Anılan, Ş. (2017). Okul öncesi öğretmenlerinin sınıf yönetimi becerileri. IBAD, 2(1), 48-58.

Yazıııoğlu, Y., \& Erdoğan, S. (2004). SPSS uygulamalı bilimsel araştırma yöntemleri. Ankara: Detay Yayıncılık.

Yeşilay-

Daşıran, T. (2013). Okul öncesi eğitimde etkili sınıf yönetimi becerilerini geliştirmeye yönelik hazırlanan hizmet içi eğitim programının etkisinin değerlendirilmesi. Yayımlanmamış Yüksek Lisans Tezi. Ankara Üniversitesi Eğitim Bilimleri Enstitüsü, Ankara.

Yıldırım, Ö. (2016). Okul öncesi öğretmenlerinin iş doyumları ile sınıf yönetimi becerileri arasındaki ilişki: Başakşehir ve Küçükçekmece örneği. (Yayımlanmamış yüksek lisans tezi). İstanbul Üniversitesi Eğitim Bilimleri Enstitüsü, İstanbul.

Yılmaz, E. (2006). Sınıf yönetimi ve yaklaşımları. İçinde R. Arı ve M.E. Deniz (Editör). Sınıf yönetimi. (s.2-20). Ankara: Nobel Yayın Dağıtım.

Yılmaz, K., \& Altınkurt, Y. (2014). Öğretmenlerin mesleki profesyonelliği ölçeği geçerlik ve güvenirlik çalışması. International Journal of Human Sciences, 11(2), 332-345.

Yılmaz, K., \& Altınkurt, Y. (2015). Öğretmenlerin mesleki profesyonellikleri ile iş-yaşam dengeleri arasındaki ilişki. Eğitim Bilimleri ve Uygulama, 14(28), 105-128.

Yirci, R. (2017). Öğretmen profesyonelliğinin önündeki engeller ve çözüm önerileri. Ahi Evran Üniversitesi Kırşehir Eğitim Fakültesi Dergisi (KEFAD), 18(1), 503-522.

Yücel, S., \& Kakırman, İ. (2017). 2016- 2017 istatistik verileri. İstanbul: İstanbul i̇ Milli Eğitim Müdürlüğü Strateji Geliştirme Bölümü.

Yüksel, S. (2004). Eğitim fakültesi öğrencilerinin öğretme-öğrenme süreçlerine yönelik direnç davranışları. Türk Eğitim Bilimleri Dergisi, 2(3), 341354.

Zembat, R., Tunçeli, H., \& Akşin Yavuz, E. (2017). Okul öncesi öğretmenlerinin sınıf yönetimi becerileri ile problem çözme becerileri arasındaki ilişkinin incelenmesi. Ahi Evran Üniversitesi Kırşehir Eğitim Fakültesi Dergisi (KEFAD) 18(3), 24-43. 